and devised initiatory and funerary rites around this (2187, study by C. Riedweg, 1236 bis, Entella, third century B.C., and 1227, Crete, first century A.D.).

Only a minority of tombs were distinguished by metrical inscriptions, which marked their owners as educated, and possessors of élite culture. A verse epitaph for Symmachos (1362, first century A.D.? Ephesos), who died at twenty-one, refers to his fellow-Ephebes, and the skill and knowledge he left behind, a reference to the curriculum of athletics and education at the gymnasium, where his age is interestingly high. Some metrical epitaphs reveal that the level of skill achieved was often not perfect: nos 974 and 980 (Kallatis and Tomis, Moesia, third/fourth century A.D.) are based on the same model, presumably literary, but that at Kallatis is less accomplished. Such feats were well beyond the resources of the majority.

Polytheism is well represented in all its rich variety, ranging from an archaic altar of Zeus Elastoros from Paros (1136, 525-500 B.C.), and dedications of kouroi to Apollo, and a Kore to Artemis from Klaros (1406-8, mid-sixth century B.C.), to lead curse-tablets from Athens (354-6, c. 375 B.C.), one of them naming Smindyrides, accused of profaning the Eleusinian Mysteries in 415 B.C., to manumission records from the sanctuary of Asklepios at Buthrotos (683-9, second century B.C.), to decrees regulating behaviour in the sanctuary of Apollo on Delos (1037, 180-166 B.C.), the conduct of wrestling at religious festivals at Olympia (541, 525-511 B.C.), and the law on manumission at Gortyn (1208, 150 B.C.), to a bronze shield trophy of a war between Hipponion and Kroton, dedicated at Olympia (546, c. 480 B.C.), and a bronze plaque listing Olympic victors (553, fourth century A.D.), created at almost the end of the pagan tradition.

Christianity is represented here by numerous mosaic inscriptions, notably including an acrostic Phos/Zoe (light, life), emblematic of two key concepts of the faith, from a sixth century A.D. church entrance in Sidon (1870), and by a lead seal from the 'Rufinion in Pergamon', a former temple of Zeus erected in the second century A.D. by the Pergamene consul L. Crispinus Pactumeius Rufinus, now belonging to the Church of the Theotokos, and under the management of 'Isidoros, her servant' (2092, sixth century A.D.).

Political life is illustrated by many legal texts, such as the land allotment decree from Delphi (592, second century A.D.), royal (783), imperial (1582), and gubernatorial (742, cf. 1514) correspondence with cities and individuals, and honorific monuments, for example, the statue-bases of Philip II of Macedon from Megalopolis (521, c. 337 B.C.), and of the Roman imperatores, L. Licinius Murena and L. Cornelius Sulla, with the evergetes Cn. Manlius Agrippa, from the agora at Messene (494-496, c. 80 B.C.). It seems that all literate classical life is here.

Institute of Classical Studies, University of London N. P. MILNER

\title{
ROMAN ARCHITECTURE
}

\section{R. Taylor: Roman Builders. A Study in Architectural Process. Pp. xvi + 303, ills. Cambridge: Cambridge University Press, 2003. Paper, £18.95/US\$25 (Cased, £50/US\$75). ISBN: 0-521-00583-3 (0-521-80334-9 hbk).}

Everything you always wanted to know about Roman buildings but were afraid to ask. This might have been a more appropriate title (or subtitle) for T.'s book, which

The Classical Review vol. 54 no. 2 (c) The Classical Association 2004; all rights reserved 
examines the realization of Roman architecture from the planning stage to the final decoration. The six chapters deal with 'Planning and Design' (Chapter 1), 'Laying the Groundwork' (Chapter 2), 'Walls, Piers, and Columns' (Chapter 3), 'Complex Armatures' (Chapter 4), 'Roofing and Vaulting' (Chapter 5), and 'Decoration and Finishing' (Chapter 6). The sequence of the book gives T. the opportunity of discussing the progress of ancient construction using a wide range of well preserved monuments, such as the Baths of Caracalla, the Pantheon, and the Colosseum. T.'s book, however, is quite different from the standard manuals of ancient building techniques. The reader will find here not a complete description of materials, walls, vaults, and so on, but a detailed analysis of all the hidden aspects of great Roman building projects. Particularly interesting is T.'s willingness to raise issues which are usually ignored, as in his previous book on the aqueducts of Rome (Public Needs and Private Pleasures: Water Distribution, the Tiber River and the Urban Development of Ancient Rome [Rome, 2000]), which is rich in subtle observations (his pages on the ancient aqueducts in the Transtiberim are surely the most interesting ever written on that topic). There is therefore no surprise that hydraulic engineers appear in almost every chapter of the present book: such a celebration of drainage and water supply in the planning and laying out of buildings is quite uncommon. The translation of drawn plans on the ground is another unusual topic, which is rightly preceded by many examples of architectural models used in ancient and even modern times. Since T. recalls the wooden models built by Michelangelo (p. 32), I would add that Brunelleschi, the architect of the dome of Florence cathedral, showed the most complicated details of the structure to his workers by means of clay, wax, wood, and, especially, big turnips. T. is also particularly concerned with the raising of colossal column shafts and stone elements during the course of a major project (the index at p. 295 reveals how many times the word 'crane' recurs in the second part of his book), and with the use of centerings in vault- and dome-construction. T.'s most original (and bold) contributions are his account of the raising of the Colosseum structure from the foundation to the upmost level, and the scenario of the construction of the Pantheon dome.

I agree with $\mathrm{T}$. that our best sources of information on Roman buildings are the buildings themselves. However, to comprehend fully a complex structure without relying on secondary sources means to devote several years of one's life to each monument. This probably explains why there are some aspects T. has overlooked. This is the case, for example, with the cranes arranged radially around the Pantheon drum at the level of the top inner cornice, and secured with stay lines to capstans anchored in the ground around the building, 'a great spray of tackle radiating from the rotunda in every direction' (p. 204): such an arrangement clashes with the construction phases and the topographical setting of the Pantheon. Sometimes it even seems that T. is keen to provoke: when he presents his ideas on the puzzling choice of twenty-eight meridians in the coffer pattern of the Pantheon dome (this number would correspond to the maximum number of cranes of the necessary height and base that could fit around the rotunda), he is aware that his 'prosaic solution to this most-discussed problem will not satisfy everyone' (p. 204). In his description of the Colosseum construction, too, T. presents his hypotheses 'not as a fact but as parallel and sequential processes that might have worked' (p. 134). This is true: there are possible counter-arguments, and other solutions are more likely.

Small lapses can be found in the text: for example, the only surviving column from the Basilica of Maxentius was re-erected (upside down) in front of S. Maria Maggiore not by Sixtus V's engineers (p. 267 n. 63), but by Paul V's. As for T.'s prose, I am not 
quite sure that ancient Romans in the Colosseum would have noticed 'the structure's ability to arrest the white-hot energy of this exploding star in cool concrete and stone' (p. 134), and I presume that nobody, admiring the Pantheon dome, would have thought that 'the wand of light penetrating the oculus probes the textured perimeter like a finger in a honey pot' (p. 248).

However, these observations aside, this book is a successful one, and achieves its main aim of providing an unusual and interesting perspective on Roman architecture. The reader can certainly learn something new, see things in a different way, and be stimulated to attempt to solve problems. When Lanciani, the great Roman topographer, was criticized for his Ancient Rome in the Light of Recent Discoveries (London, 1888), he replied: 'I have tried to make subjects, otherwise dry or heavy to digest, agreeable and pleasant to the general public . . . and I have succeeded . . . Had I written it in the old style of puritan science, I could not have sold a hundred copies' (from a letter preserved in the copy of the Sackler Library, Oxford). Given that T.'s primary aim is not to sell as many copies as possible but to share his enthusiasm with the reader, it is worth quoting his introduction, where he states that he wishes 'to evoke, if only hypothetically, the cultural and cognitive process involved in the act of creating buildings'. Like Lanciani one century ago, he has succeeded.

University of Rome 'La Sapienza'

PIER LUIGI TUCCI

\section{ILLUSTRATIONS?}

J. P. Small: The Parallel Worlds of Classical Art and Text. Pp. xvi + 253, ills. Cambridge: Cambridge University Press, 2003. Cased, $£ 55 /$ US\$75. ISBN: 0-521-81522-3.

The Parallel Worlds of Classical Art and Text is a beautifully produced book with a distinctly iconoclastic message. The images of classical art have often suffered from underinformed use by literary and historical scholars, and Jocelyn Penny Small has been a notable opponent of this tendency; she has published widely on classical art and archaeology, holding received opinion up to searching scrutiny (J. P. Small, 'Scholars, Etruscans and Attic Painted Vases', JRA 7 [1994], 34-58, on the fallacy of 'sets'). In this study, S. examines the relationship of ancient artists to texts, focusing on the nature of illustration, the rôle of the artist in creating a visual tradition, ancient conceptions of 'imitation' and 'translation', and the differing nature of storytelling in visual and textual modes.

S. has an engaging and informal style, and states her conclusions with clarity and enthusiasm. After an introduction which tackles the question of what 'illustration' means, the book works chronologically through a series of case studies: the field of enquiry is defined at the outset as those objects for which both text and image exist, and $\mathrm{S}$. examines a series of visual representations of stories (which are themselves generously illustrated).

The first two chapters treat Greek pots, looking at depictions of Homer and representations of drama. The Homeric scenes introduce several key theoretical points: the general lack of reference to texts, the use of salient detail to identify textual models (which S. finds generally unconvincing), the way that Greek artists combined stock and heroizing motifs with the contemporary. The images bear out these points: the piebald horse, for instance, which appears in a Corinthian representation of the funeral games of Pelias, neatly demonstrates how painters had to develop their own

The Classical Review vol. 54 no. 2 @ The Classical Association 2004; all rights reserved 